\title{
Status Distinctions and Sartorial Difference: Slavery, Sexual Ethics, and the Social Logic of Veiling in Islamic Law
}

\author{
Omar Anchassi \\ School of Divinity, The University of Edinburgh, Edinburgh, \\ United Kingdom \\ omaranchassi@gmail.com
}

\begin{abstract}
This article explores how jurists articulated the distinction between free and enslaved Muslim women through sartorial norms in the formative and early post-formative periods of Islamic law. Drawing on works of figh (positive law), tafsìr (Qurān commentary) and hadith (Prophetic and non-Prophetic reports), I posit that this distinction attests to the tensions between "proprietary" and "theocentric" sexual ethics, as noted by Hina Azam. Specifically, I track the variant transmissions of a widely-cited report featuring the Caliph 'Umar (r. 13-23/634-44), and trace how jurists responded to the free-slave binary in their discussion of "modesty zones" ('awrāt) and veiling practices. Based on a detailed examination of figh sources to the early fifth Islamic century (with some attention to subsequent material), I argue that Islamic modesty norms are best understood in light of the proprietary/theocentric binary, and that the divergence between juristic expectations of free and enslaved women increased in the post-formative period.
\end{abstract}

\section{Keywords}

slavery - veiling - 'Umar - fitna - modesty - 'awra

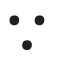

As for what has been reported about the jurists of the garrison towns (fuqahā' al-amșār), who permit a woman to expose her face and hands, 
this is restricted to [cases in which] there is no fear of temptation (fitna). Where can such a well-behaved society-in which a person is safe from the fear of temptation when women go about unveiled — be found?

ZĀHID AL-KAWTHARĪ (D. 1371/1951) ${ }^{1}$

If only 'Umar, God be pleased with him, had raised his switch (dirra) against those men who used to harass women at night...instead of raising it against that poor woman who only wanted to protect herself...from harassment! Perhaps there was [in his actions] some wisdom hidden from the likes of me.

NAZ̄īRA ZAYN AL-DĪN (D. 1396/1976) ${ }^{2}$

\section{Introduction}

In her feminist polemic al-Sufür wa-l-hijäb (Unveiling and Veiling, 1346/1928), the Lebanese Druze activist Nazīra Zayn al-Dīn pauses to recount a list of discriminatory measures imposed on non-Muslim residents of the Muslim polity. Her source is the Damascene Ḥanafí jurisconsult Ibn 'Ābidīn (d. 1258/1842). ${ }^{3}$ Among

Muḥammad Zāhid al-Kawtharī, "Hijāb al-mar’a," in Maqālāt al-Kawtharī (Cairo: Dār al-salām, 1430/2009), 187-9o, at 188. On fasād al-zamān (corruption of the present age), see Behnam Sadeghi, The Logic of Law Making in Islam: Women and Prayer in the Legal Tradition (New York: Cambridge University Press, 2013), 113-23, 139-40. See also Marion Holmes Katz, Women in the Mosque: A History of Legal Thought and Social Practice (New York: Columbia University Press, 2014), 68-70. For another example of a member of the Ottoman learned hierarchy defending veiling, see Muștafā Șabrī (d. 1373/1954), Qawlì fì l-mar'a (Beirut: Dār Ibn Ḥazm, n.d.), 25-39. Naẓīra Zayn al-Dīn, "al-Sufūr wa-l-hijāb," in al-Sufür wa-l-hijāb wa Nazarāt fì Kitāb al-Sufūr wa-l-hijāa, Fāțima Ḥāfiz introd. (Cairo and Beirut: Dār al-kitāb al-mișrī with Dār al-kitāb al-lubnānī, 1434/2012), section 2: 249. On 'Umar's switch, see Ibn Abī Shayba, Muṣannaf Ibn Abī Shayba, ed. Muhammad 'Awwāma, 16 vols. (Jeddah: Dār al-qibla, 1427/2006), 4: 344, footnote 6295. I thank Tariq al-Timimi for bringing this reference to my attention. For Ibn 'Ābidīn's views, see Radd al-muhtār 'alä l-Durr al-mukhtār, 6 vols. (Beirut: Dār al-fikr, 1412/1992), vol. 4: 209-11. According to miriam cooke, prior to the French Mandate in Lebanon, "Druzes educated in Ottoman legal establishments [e.g. Zayn al-Dīn's father] were considered on a par with orthodox Muslims by virtue of their mastery of Islamic law," see miriam cooke, Nazira Zeineddine: A Pioneer of Islamic Feminism (Oxford: Oneworld, 2010), 24. One wonders if Zayn al-Dīn's animus for Ibn 'Ābidīn is motivated by Ibn 'Ābidīn's view that the Druze are apostates. See Radd al-muhtārr, 4: 175. On the ghiyār, see Milka Levy-Rubin, Non-Muslims in the Early Islamic Empire: From Surrender to Coexistence 
other ghiyār (distinctions) pertaining to dhimmīs, she notes the prohibitions on building lofty residences, ownership of slaves and slave-concubines, and the wearing of expensive garments. ${ }^{4}$ The relevance of these remarks to her larger argument about women quickly becomes apparent. "These sartorial restrictions (quyūd al-malābis)... [facilitate] the identification of non-Muslims...so people can treat them accordingly. This is naught but an innovation (bid'a), like the innovation of veiling women - those poor ones subject to humiliation and abasement (șaghār). ${ }^{n}$ According to Zayn al-Dīn, the hijā $\bar{b}$ is a pernicious custom (much like the ghiyār), one that degrades women and has no basis in the Qurān or Sunna-a critique shared by other reformists of the period. ${ }^{6}$ By "hijäb," she refers to the veiling of the face and the accompanying system of sexual segregation, the standard referent of the term in the early fourteenth/twentieth century

(Cambridge: Cambridge University Press, 2011), 88-98. On tashabbuh (imitation), see Youshaa Patel, "Muslim Distinction: Imitation and the Anxiety of Jewish, Christian, and Other Influences," unpublished PhD dissertation, Duke University, 2012. Zayn al-Dīn observes that the view requiring the covering of the face (with the exception of one eye) is that of "no Muslim [group], except for the Druze," thus pitting herself against her own community. See "al-Sufür wa-l-hijāb," 255.

Zayn al-Dīn, "al-Sufūr wa-l-hijāb," 389, 396-98. On non-Muslims in the Muslim polity (as envisioned by the jurists), see Yohanan Friedmann, Tolerance and Coercion in Islam: Interfaith Relations in the Muslim Tradition (Cambridge: Cambridge University Press, 2003). On the abrogation of Muslim hegemony and the emergence of an "ecumenical frame" in the Ottoman Middle East, see Ussama Makdisi, Age of Coexistence: The Ecumenical Frame and the Making of the Modern Arab World (Oakland: University of California Press, 2019), 27-74.

5 Zayn al-Dīn, "al-Sufūr wa-l-hijāb," 399.

6 On Qāsim Amīn (d. 1326/19o8), see The Liberation of Women [Tahrīr al-mar'a] and The New Woman [al-Mar'a al-jadida]: Two Documents in the History of Egyptian Feminism, trans. Samiha Sidhom Peterson (Cairo: American University in Cairo Press, 200o), 35-45. See also Barbara Freyer Stowasser, Women in the Qur'an, Traditions, and Interpretation (New York: Oxford University Press, 1994), 127-28. On al-Manār-and specifically Muḥammad Tawfíq Ṣidqī (d. 1338/1920) — see "Hijāb al-mar’a fī l-islām (1)," al-Manār, 13 (Ramaḍān 1328/October 1910), 689-93 and "Hijāb al-mar’a fì l-islām (2)," al-Manār, 13 (Shawwāl 1328/November 1910), 771-78. The defense of veiling is associated with what Jonathan A. C. Brown calls "Late Sunni Traditionalism." Jonathan A. C. Brown, Hadith: Muhammad's Legacy in the Medieval and Modern World (Oxford: Oneworld, 20o9), 261-63. The veil was also defended by many modernists, including the banker Muhammad Țal'at Ḥarb (d. 1360/1941). See Muḥammad Țal'at Ḥarb, Tarbiyyat al-mar'a wa-l-hijāb (Cairo: Maktabat al-taraqqī, 1317/1899). The obligation to cover the face is also associated with the Wahhabis, who were marginal to intellectual life in the period. On al-Kawtharī, see Jonathan A. C. Brown, Misquoting Muhammad: The Challenges and Choices of Interpreting the Prophet's Legacy (Oxford: Oneworld, 2014), 114-15; Ahmed El Shamsy, Rediscovering the Islamic Classics: How Editors and Print Culture Transformed an Intellectual Tradition 
Arabophone world. ${ }^{7}$ The rationale for the practice, she argues, is evident in the tafsir (Qurān commentary) literature, where one finds that it distinguishes free women from enslaved believing women. " "This rationale ( $q$ așd) is confirmed by ... [the account in which] a slave woman [whose dress] resembled that of a free woman passed by 'Umar b. al-Khaț̣āb...who reproached her, exclaiming 'O base one $(y \bar{a} l u k \bar{a})$, are you trying to imitate free women?"'

Zayn al-Dìn was not the first person to invoke the encounter between the Caliph 'Umar and a slave woman to make a point about status distinction and sartorial practices in Islamic law. In this case, as miriam cooke explains, Zayn al-Din deploys it to argue that "since slavery was a practice of the past, the instrumental function of the veil no longer pertained." ${ }^{10}$ If slavery no longer exists, in other words, the rationale for and the obligation of veiling disappear. The 'Umar report-and its numerous variants-was subject to centuries of debate by jurists. The common core of the narrative is a confrontation between the Caliph and another person (or persons) about the dress of a slave (or slaves) in Medina, dress that visibly subverts the distinction between free and enslaved women.

(Princeton: Princeton University Press, 2020), 212-17. For a useful—albeit polemicalaccount of the early veiling debate, see Muḥammad Ismāill al-Muqaddam, 'Awdat al-hijāă, 3 vols. (Riyadh: Dār țayyiba, 1427/20o6), vol. 1. On the influence of Muslim veiling norms on dhimmī communities, see e.g. Yedida Kalfon Stillman, "Cover the Face: Jewish Women and Veiling in Islamic Civilisation," in Studies in Muslim-Jewish Relations, ed. Tudor Parfitt (Curzon: Richmond, 2000), 13-31.

On the meaning of "hijäb" in the early fourteenth/twentieth century Arabophone world, see Beth Baron, "Unveiling in Early Twentieth-Century Egypt: Practical and Symbolic Considerations," Middle Eastern Studies, 25:3 (1989), 370-86, at 370. On the veiling debate generally, see idem, The Women's Awakening in Egypt: Culture, Society, and the Press (New Haven: Yale University Press, 1994), 33-34, 39-40, 47.

For early interpretations of Q. 33:59 see, for example, Muqātil b. Sulaymān (d. 15०/767), Tafsīr, ed. 'Abd Allāh Muḥammad Shiḥāta, 5 vols. (Beirut: Mu’assasat al-tārīkh al-'arabī, 1423/2002), 3: 507; Yahyā b. Sallām (d. 200/815), Tafsìr Yahyā b. Sallām, ed. Hind Shalabī, 4 vols. (Amman: Mu’assasat āl al-bayt, 1329/2008), 1: 440-41; 'Abd al-Razzāq al-Ṣanānī (d. 211/826), Tafsīr 'Abd al-Razzāq, ed. Maḥmūd Muḥammad 'Abduh, 3 vols. (Beirut: Dār al-kutub al-ilmiyya, 1419/1999), 3: 5, and Muhammad b. Jarīr al-Ṭabarī (d. 310/923), Tafsìr al-Ṭabarī: Kitāb Jāmi' al-bayān 'an ta’wīl āy al-Qur'ān, ed. 'Abd Allāh b. 'Abd al-Muḥsin al-Turkī, 26 vols. (Cairo: Hijr, 1422/20o1), 19: 181-83. See also Fatima Mernissi, The Veil and the Male Elite: A Feminist Interpretation of Women's Rights in Islam, trans. Mary Jo Lakeland (New York: Perseus, 1991), 180-88.

9 Ibid., 249. The word luka $u$ is found frequently in variants of the report, as noted in the relevant section of this article.

10 miriam cooke, Nazira Zeineddine, 56. cooke emphasizes the irony of Zayn al-Dīn's appeal to the obsolesence of slavery; her family owned four female slaves. 
In this article, I trace the various transmissions of the 'Umar report and aspects of its citation in a range of literary genres-without adopting a position on its historicity - to shed light on the question of the veiling of slaves in Islamic law. ${ }^{11}$ I hope to make a number of key interventions. Firstly, I attempt to characterize the relevant qurānic data, drawing on the tafsir literature; secondly, I map juristic opinion on the question of veiling, highlighting the increased emphasis on the fear of fitna (sexual temptation) in early post-formative (i.e. third-early fifth/ninth-early eleventh centuries) discussions of sartorial regulation. Finally, I highlight juristic disagreements over modesty norms as they apply to slave women. In this context, I make some brief observations about opinions in later periods, down to the thirteenth/ nineteenth centuries. My larger argument relates to the study of Islamic norms in their Ancient and Late Antique Near Eastern contexts, building on existing scholarship on veiling practices. ${ }^{12}$ For example, Hina Azam has written about the distinction between "proprietary" and "theocentric" systems of sexual ethics, an important conceptual framework that will undergird the analysis below..$^{13}$ Given the importance of this framework, I shall summarize some of its key features as they relate to my argument.

In systems of proprietary sexual ethics, Azam informs us, a woman's sexuality is a commodity subject to sale and purchase. The "theft" of that sexuality through rape, for example, is punished like other property crimes, including financial compensation to the owner (in the case of a virgin, her father), among other measures. In this view, God or the gods have little concern with sexuality, and illicit sexual relations are less an affront to the deity than an infringement of someone's entitlement to financial reward for the sale of sexual access. ${ }^{14}$ By contrast, the qurannic intervention is decidedly theocentric, although it retains elements of the proprietary ethic. Illicit sex, as in the Hebrew Bible, is a moral

On Ḥanafì modesty norms, see Shiu-Sian Angel Hsu, "Dress in Islam: Looking and touching in Ḥanafï fiqh," unpublished PhD dissertation, University of Utah, 1994 (esp. 24-27). See also idem, $E Q$, "Modesty."

See Leila Ahmed, Women and Gender in Islam: Historical Roots of a Modern Debate (New Haven: Yale University Press, 1992), 14-15; Stowasser, Women in the Qur'an, Traditions, and Interpretation, 92-93; idem, "The Hijäb: How a Curtain Became an Institution and a Cultural Symbol," in Humanism, Culture and Language in the Near East: Studies in Honor of Georg Krotkoff, ed. Asma Afsaruddin and A. H. Mathias Zahniser (Winona Lake: Eisenbrauns, 1997), 83-104, at 94-96; Khairunessa Dossani, "Virtue and Veiling: Perspectives from Ancient to Abbasid Times," unpublished MA dissertation, San Jose State University, 2013, 14-72. Cambridge University Press, 2015), 23-26. Ibid., 27-29. 
crime, a sin against an all-knowing and ever-watchful God. Those guilty of it are subject to punishment by scourging. Financial compensation plays a secondary role or no role at all in this scheme, according to Muslim jurists. ${ }^{15}$ In proprietary terms, however, the Qurān retains the practice of mahr (dower, e.g. Q. 4:24), which was conceptualized by jurists as the "vulva's price" (thaman al-bud'), clearly a reminder of earlier legal systems. Modern scholarship has debated the extent to which marriage resembles a contract of sale in Islamic law, but the term thaman al-bud' does help explain key features of juristic reasoning on marriage, as Kecia Ali has argued. ${ }^{16}$ In this article I propose that veiling practices should be read in the context of competing systems of sexual ethics. I will argue that veiling, along with other elements of Islamic modesty norms, should be seen as a combination of proprietary and theocentric values. The distinctions between free and enslaved Muslim women — noted and sometimes critiqued by classical Muslim jurists-highlight these tensions. I should note that I foreground a particular aspect of Azam's argument in my analysis. For the purposes of this article, the proprietary ethic is not so much about the ownership claims of masters or mistresses over their enslaved persons, and the corresponding control of their slaves' (commodified) sexuality. In this article, I am more interested in the implications of the commodification of slaves and their sexual capacity for modesty norms themselves. In other words, how and to what extent does the fact that slaves are considered property nuance the theocentric dimensions of veiling?

\section{Variants of the 'Umar Report}

To better appreciate the implications of the 'Umar report for the veiling of slaves, and the development of Islamic modesty norms more generally, I document and translate its variants below. I present these variants in chronological order, except when there are multiple transmissions of an earlier work, e.g. in the Muwatta. Though the provenance of some of the texts below has been disputed, I do not discuss arguments for or against their authenticity. ${ }^{17}$ Even

15 Azam notes that the Hanafis adopt a clearly theocentric view, entirely disregarding financial compensation for sexual violation. The Mālikīs, however, accept the possibility of physical scourging accompanied by the payment of dower as compensation. See ibid., 147-69 and 114-46, respectively. Harvard University Press, 2010), 6o. On marriage as a commercial or social exchange, see ibid., 61, 171-72.

17 On the attribution of the Kitāb al-Āthār to Muhammad b. al-Hasan, see Sadeghi, The Logic of Law Making, 177-96. On the attribution of the Muwatța' to Mālik b. Anas, see, for 
if they represent later texts back-projected onto more illustrious transmitters, this does not significantly undermine my argument, which is a cumulative one. For illustrative purposes, I attempt to characterize the transmitters who lived in the first two Islamic centuries in terms of garrison town. Frequently, such characterizations are less than adequate, as in the case of Ibn Shihāb al-Zuhrī (d. 124/742), whose rich and varied career as a traditionist, courtier and sometime tutor to Umayyad princes is not fully captured by his "Medinan" affiliation. Nonetheless, hadith continued to be transmitted locally until the later years of the second/eighth century. In cases where the original texts provide isnāds, I present them here. For the sake of comprehensiveness, I include a number of citations of the report found outside of the usual hadith and figh works in the first four Islamic centuries. This is because the transmitters of these texts cannot be assumed to be dependent on the earlier hadith sources, which had not become "canonical." Similarly, I present a number of later variants without isnāds when they feature interesting vocabulary or additional details not found in earlier attestations. In such cases, I include only the earliest attestation of these variants.

1. Ibn Bukayr (d. 231/845) - Mālik b. Anas (Medinan, d. 179/795): 'Umar b. al-Khațtāb saw a slave woman belonging to 'Ubayd Allāh b. 'Umar b. al-Khațtāb mingling (tajūsu) with people and dressed in the apparel of free women (tahayya'at bi-hay'at al-harä'ir). He met with his daughter, Hafșa, and asked, "Did I just see your brother's slave woman going about [so dressed]?" 'Umar b. al-Khațtāa condemned this [behavior].18

2. Yaḥyā b. Yaḥyā al-Laythī (d. 234/848) - Mālik b. Anas: 'Umar b. al-Khațāāb saw a slave woman belonging to 'Abd Allāh b. 'Umar b. al-Khaț̣āb...'Umar condemned this [behavior]. ${ }^{19}$

3. Abū Muṣ́ab al-Zuhrī (d. 242/856) - Mālik b. Anas: identical to report 1 above, except for the final mention of 'Ibn al-Khaț̣āb.'20

example, Yasin Dutton, The Origins of Islamic Law: The Qur'an, the Muwatta' and Madinan Amal (Richmond: Curzon, 1999), 24-27.

18 Al-Muwațta' [riwāyat Ibn Bukayr al-Mișīi], ed. Bashshār 'Awwād Ma'rūf and Muḥammad 'Alī al-Azharī, 3 vols. (Beirut: Dār al-gharb al-islāmī, 2020), 3: 566-67.

Mālik b. Anas, al-Muwațta' [riwāyat Yahyā b. Yahyyā al-Laythī], ed. Muhammad Fu’ād 'Abd al-Bāqī, 2 vols. (Beirut: Dār ị̣yā̄ al-turāth al-'arabī, 1406/1985), 2: 981. The Royal Moroccan edition substitutes 'Ubayd Allāh for 'Abd Allāh: al-Muwaț̣ta' [riwāyat Yahyā b. Yahyā al-Laythī], 2 vols. (Casablanca: Manshūrāt al-majlis al-ilmī al-a'āa, 1434/2013), 2: 345 .

20 Al-Muwatța' [riwāayat Abī Mușáab al-Zuhrī], ed. Bashshār 'Awwād Márūf and Maḥmūd Muḥammad Khalīl, 2 vols. (Beirut: Mu’assasat al-risāla, 1434/2013), 2: 161. 
4. Yūsuf b. Abī Yūsuf (Kufan, d. c. 200/815-6) - al-Q̣ạḍi Abū Yūsuf (Kufan, d. 182/789) - Abū Ḥanīfa (Kufan, d. 150/767) - Ḥammād b. Abī Sulaymān (Kufan, d. 120/738) - Ibrāhīm al-Nakha'ì (Kufan, d. 96/714): Slave women are not obligated to veil (laysa 'alā al-īmā qina $\overline{\text { }}$ ) for prayer or otherwise. [People] used to consider it reprehensible (yukrah) that slave women veil, making them resemble free women. ${ }^{21}$

5. Muḥammad b. al-Ḥasan (Kufan, d. 189/804) - Abū Ḥanīfa - Ḥammād b. Abī Sulaymān - Ibrāhīm al-Nakha'ĩ: 'Umar b. al-Khaț̣āb—may God be pleased with him — used to strike slave women for veiling, saying, "Do not imitate free women (lā tatashabbahina bi-l-harǟir)!"22

6. Yaḥyā b. Sallām (Basran, d. 20o/815) - Sa'īd b. Bashīr (Basran, d. 168/7845) - Qatāda b. Di'āma (Basran, d. 117/735) - Anas b. Mālik (Basran, d. 93/712): 'Umar b. al-Khatțāb saw a slave woman wearing a veil and struck her with his switch. Saìd added, "He poked her with his switch, commanding "uncover your head!" Sa'îd added, "Do not imitate free women." 23

7. 'Abd al-Razzāq al-Ṣan'ānī (d. 211/826) - Ibn Jurayj (Meccan, d. 150/767) 'Ațā' b. Abī Rabāḥ (Meccan, d. 114/732): 'Umar b. al-Khaț̣āb used to forbid slave women from wearing robes (jalābìb) and imitating free women. ${ }^{24}$

8. 'Abd al-Razzāq al-Ṣan'ānī - Ibn Jurayj: I was informed that 'Umar b. al-Khațtāb struck 'Aqīla, a slave woman belonging to Abū Mūsā al-Ash'arī, for wearing a robe. ${ }^{25}$

9. 'Abd al-Razzāq al-Șanānī - Ma'mar b. Rāshid (Basran, d. 153/770) Ayyūb al-Sakhtiyānī (Basran, d. 131/748) - Nāfic (Medinan, d. 117/735): 'Umar saw a slave woman leave Hafșa's house-or perhaps it was a house of one of the wives of the Prophet-dressed in a robe. 'Umar entered the house, asking "Who is this slave woman?" They answered, "A slave woman of ours" - or they said, "A slave woman belonging to the family of

Abū Yūsuf, Kitāb al-Āthār, ed. Abū l-Wafā' al-Afghānī (Beirut: Dār al-kutub al-ilmiyya, n.d.), 29. I have included this report because it seems to be a variant of version 5 , reported from the same isnād to Abū Ḥanīfa.

Muḥammad b. al-Ḥasan al-Shaybānī, Kitāb al-Āthār, ed. Abū l-Wafā’ al-Afghānī, 2 vols. (Beirut: Dār al-kutub al-ilmiyya, 1413/1993), 1: 611-12.

Yahyā b. Sallām, Tafsìr, 441. He also reports that Anas b. Mālik said, "Umar's slave women used to serve us with their heads uncovered, their breasts knocking together and their anklets exposed." For a corroborating report, see Abū Bakr Muḥammad b. al-Ḥusayn al-Bayhaqī, al-Sunan al-kubrā, ed. Muhammad 'Abd al-Qādir 'Ațā, 10 vols. (Beirut: Dār al-kutub al-ilmiyya, 1424/2003), 2: 320-21.

24 'Abd al-Razzāq b. Hammām al-Ṣanēnī, Mușannaf 'Abd al-Razzāq, 11 vols. (Dār al-ta’ṣīl, 1436/2015), 3: 89 .

Ibid. 
so-and-so" - whereupon 'Umar became angry, asking, "Do you send your slave women out in all their finery, tempting people?"26

10. 'Abd al-Razzāq al-Șanāāī - Ibn Jurayj - Nāfic - Șafiyya bt. Abī 'Ubayd (Medinan, d. after 73/692-3): When 'Umar was preaching he saw a slave woman leaving the house of Hafșa dressed as a free woman. When 'Umar [finished preaching], he met with Ḥafșa and asked, "Who is this woman who left your house, mingling with the menfolk?" She answered, "A slave woman belonging to [your son] 'Abd al-Rahmān." ['Umar asked] "What led you to dress your brother's slave woman in the dress of free women? I entered thinking she was a free woman, and wished to punish her."27

11. 'Abd al-Razzāq al-Ṣan'ān̄ - Ma'mar b. Rāshid - Qatāda b. Di'āma - Anas b. Mālik: 'Umar struck a slave woman belonging to the family of Anas for wearing a veil, saying, "Uncover your head! Do not imitate free women!"28

12. 'Abd al-Razzāq al-Ṣan'ānī - Sufyān b. 'Uyayna (Kufan, d. 198/813-4) - 'Amr b. Dīnār (Meccan, d. 126/744) - al-Ḥasan b. Muhammad b. al-Ḥanafiyya (Medinan, d. 10o/718-9): 'Umar b. al-Khatțāb used to forbid slave women from wearing robes. ${ }^{29}$

13. Saīd b. Manșūr (d. 227/841-2) - Hushaym b. Bashīr (Baghdadian, d. 188/8o3) - Khālid b. Mihrān al-Ḥadhdhā' (Basran d. 141/758) - Abū Qilāba 'Abd Allāh b. Zayd (Basran, d. 104/722-3): During his caliphate, 'Umar b. al-Khațtāb would not permit any slave women to go about veiled. He would say, "The veil is only for free women, so that they will not be harassed."30

14. Ibn Abī Shayba (d. 235/849) - Wakī̄ b. al-Jarrāḥ (Kufan, d. 197/812-3) - Shu'ba b. al-Ḥajjāj (Basran, d. 16o/777) - Qatāda b. Di'āma - Anas b. Mālik: When 'Umar saw my slave woman wearing a veil, he struck her, saying, "Do not imitate free women!" 31

15. Ibn Abī Shayba - 'Abd al-A' lā b. 'Abd al-A'lā (Basran, d. 189/8o5) - Ma'mar b. Rāshid - Ibn Shihāb al-Zuhrī (Medinan, d. 124/742) - Anas b. Mālik: When 'Umar saw a slave woman wearing a veil he struck her, saying "Do not imitate free women!"32

\footnotetext{
26 Ibid., 9o.

27 Ibid.

28 Ibid.

29 Ibid.

30 Sacīd b. Manșūr, Sunan Saìd b. Manșūr, ed. Ḥabīb al-Raḥmān al-A`ẓamī, 2 vols. (Bombay: al-Dār al-salafiyya, 1403/1982), 2: 98-99.

31 Abū Bakr b. Abī Shayba, Muṣannaf Ibn Abī Shayba, ed. Abū Muḥammad Usāma b. Ibrāhīm, 15 vols. (Cairo: al-Fārūq al-ḥadītha, 1429/2008), 3: 114. Ibid., 115 .
} 
16. Ibn Abī Shayba - 'Alī b. Mushir (Kufan, d. 189/8o4-5) - al-Mukhtār b. Fulful (Kufan, d. c. 140/757-8) - Anas b. Mālik: 'Umar b. al-Khațțāb came across a slave woman whom he knew was owned by one of the Emigrants or Helpers. She veiled herself with [a loose end of] her robe. He asked her, "Have you been manumitted?" She answered in the negative. He asked, "Then why [are you wearing] a robe? Remove it from your head! The robe is only for free believing women!' When she dawdled (talakka'at), 'Umar struck her with his switch until she dropped [the loose end of] her robe from her head. ${ }^{33}$

17. Ibn Abī Shayba - Hushaym b. Bashīr - Khālid b. Mihrān al-Ḥadhdhā̄ Abū Qilāba 'Abd Allāh b. Zayd: During his caliphate, 'Umar b. al-Khațtāâ would not permit any slave women to veil. He would say, "The veil is only for free women, so that they will not be harassed." ${ }^{34}$

18. 'Abd al-Malik b. Ḥabīb (d. 238/852) - Anas b. Mālik: 'Umar b. al-Khațāāb saw a slave woman belonging to one of his companions wearing a head covering (mukhtamira). He asked her, "Has your master manumitted you?" She answered in the negative. He asked, "Then why are you wearing a robe? Put it aside (daich)!" When she refused, he hit her with his switch until she complied, proclaiming, "Do not imitate free women ever again!"35

19. 'Abd al-Malik b. Habīb - Anas b. Mālik: 'Umar came to his family one day and noticed that there was a woman in his house wearing a robe. When he saw her, he left. When he returned and saw her again, he left (inșaraf) again. He did this several times, until she departed. He then entered, asking, "Who is this who has been bothering us today?" His wife responded, "What do you have to do with her? She is so-and-so's slave woman." When ['Umar] left he proclaimed to the people, "Do not let slave women resemble their mistresses! Do not dress them in robes such that they resemble free, chaste women (al-ḩaräir wa-l-muhșanāt)! God the [most] exalted said (Q. 33:59) “...O Prophet, tell your wives, your daughters and believing women to cover themselves with their robes." ${ }^{36}$

20. Hūd b. Muhạkkam (d. c. 290/903): 'Umar b. al-Khațāâb saw a slave woman wearing a veil, and he raised his switch against her, saying, "Uncover your head! Do not imitate free women!" They [viz. his sources among

\footnotetext{
33 Ibid.

34 Ibid.

35 'Abd al-Malik b. Habīb, Kitāb Adab al-nisā' al-mawsūm bi-Kitāb al-Ghāya wa-l-nihāya, ed. 'Abd al-Majīd al-Turkī (Beirut: Dār al-gharb al-Islāmī, 1412/1992), 228. Ibid.
} 
the learned] added that Anas b. Mālik reported, "The slave women of 'Umar used to serve us with their heads uncovered, their breasts knocking together and their anklets exposed."37

21. Al-Māturīdī (d. 333/944): It is reported that a slave woman passed by 'Umar b. al-Khaț̣āb — may God be pleased with him — wearing a veil. He struck her with his switch and said, "Remove your veil (ikshifi qināi $i k$ ) and do not imitate free women!"38

22. Al-Qāọī al-Nu'mān (d. 363/974) - Ja'far b. Muḥammad al-Ṣādiq (Medinan, d. 148/765) - upon whom be peace-was asked if slave women are required to veil during prayer. He answered, saying, "No, and when my father-may God be pleased with him—saw a slave woman praying in a veil, he would strike her, saying, 'Do not imitate free women, you moron (luka'u)!' This was [so] that free women would be distinguishable from slave women."39

23. Al-Jașșāṣ (d. 370/981): It is reported that 'Umar used to strike slave women and order them to uncover their heads and not to imitate free women. ${ }^{40}$

24. Ibn Abī Zamanīn (d. 399/10o8) - Yaḥyā b. Sallām - Sa'ìd b. Bashīr and 'Uthmān b. Miqsam al-Burrī (Basran, d. 163/779-80) - Qatāda b. Di'āma - Anas b. Mālik: 'Umar saw a slave woman wearing a veil. He struck her with his switch — according to the version of Sa ${ }^{a} \mathbf{i}$ — and in the version of 'Uthmān, "['Umar] raised his switch against her and said, 'Uncover your head!" In the version of Sa'īd he said, "Do not imitate free women!"41

25. Ibn Abī Zamanīn - Yaḥyā b. Sallām - Saīì b. Bashīr - Qatāda b. Di'āma - Anas b. Mālik: When 'Umar b. al-Khațāāb saw a slave woman wearing a veil, he raised his switch against her, commanding, "Uncover your head and do not imitate free women!"42

Hūd b. Muhakkam al-Huwwārī, Tafsīr kitāb Allāh al-'azīz, ed. Bālhạāj b. Saīìd Sharīî̀, 4 vols. (Beirut: Dār al-gharb al-islāmī, 199o), 3: 174. Also ibid., 382 .

38 Abū Manșūr Muhammad b. Muḥammad al-Māturīdī, Ta’wīlāt al-Qur'ān, ed. Ahmet Vanioğlu et al., 18 vols. (Istanbul: Dār al-mīzān, 2007), 2: 385 .

Al-Qāạī al-Nưmān, Dacăìm al-islām, ed. A. A. A. Fyzee, 2 vols. (Cairo: Dār al-Macārif, 1383/1963), $1: 187$.

Abū Bakr Aḥmad b. 'Alī al-Jașșāṣ, Aḥkām al-Qur'ān, ed. Muḥammad al-Ṣādiq Qamḥāwī, 5 vols. (Beirut: Dār ihyā̄ al-turāth al-'arabī with Mu’assasat al-tārīkh al-'arabī, 1412/1992), 5: 174. See also idem, Sharh Mukhtașar al-Ṭahāōwī, ed. 'Iṣmat Allāh Ināyat Allāh et al., 8 vols. (Beirut: Dār al-bashāìr al-islāmiyya with Dār al-sirāj, 1431/2010), 1: 702. 
26. Al-QQậ̣ī 'Abd al-Wahhāb al-Mālikī (d. 422/1035): It is reported that 'Umar b. al-Khațtāb—may God be pleased with him —used to strike slave women if he saw them wearing a waist-cloth (izār), saying, "Do not imitate free women!" He rebuked his son, saying, "Did I not tell you that your slave woman was walking about in a waist-cloth imitating free women? If I come across her [doing so] I will administer a painful beating (la-awja tuhā darban)."43

27. Abū Isḥāq al-Tha labī (d. 427/1035) - Anas b. Mālik: A veiled slave woman passed by 'Umar b. al-Khațāāb, who raised his switch against her, saying, "O base one $(y \bar{a} l u k \bar{a})$, are you trying to imitate free women? Put aside your veil!"44

28. Al-Bayhaqī (d. 458/1066) - Abū Sa'ìd b. Abī 'Amr (d. 421/1030 ${ }^{45}$ Abū l-'Abbās Muḥammad b. Ya'qūb (d. 277/89o-1) - Aḥmad b. 'Abd al-Ḥamīd al-Ḥārithī (d. 269/883) - Abū Usāma Ḥammād b. Usāma (Kufan, d. 201/817) - al-Walīd b. Kathīr al-Makhzūmī (Medinan, d. 151/768-9) - Nāfi' - Șafiyya bt. Ab̄̄ 'Ubayd: A robed and veiled woman was walking about [in Medina] and 'Umar — may God be pleased with him - asked who she was. He was told that she was the slave woman of one of his sons. He sent for Ḥafșa-may God be pleased with her-asking, "What made you veil and robe this slave woman, causing her to resemble free women, such that I thought of accosting her (an aqa'u $b i h \bar{a})$, thinking she was free? Do not have your slave women resemble free women!" 46

29. Al-Sarakhsī (d. 483/109o): 'Umar-may God be pleased with himwould raise his switch against any slave woman who walked about veiled, saying, "Put your head-cover aside, oh odious one ( $y \bar{a}$ difār $)$ ! Are you trying to resemble free women?" 47

Al-Qāḍī 'Abd al-Wahhāb al-Mālikī, al-Ma ūna 'alā madhhab 'ālim al-madīna, ed. Ḥamīsh 'Abd al-Ḥaqq, 3 vols. (Mecca: al-Maktaba al-tijāriyya, n.d.), 1: 230.

Abū Isḥāq al-Tha'labī, al-Kashf wa-l-bayān 'an tafsìr al-Qur'ān, ed. Ibn 'Āshūr, 10 vols. (Beirut: Dār ihyā̄' al-turāth al-'arabī, 1422/2002), 8: 64. 1: 121. Also 10: 151, where he includes a curious variant of Anas's report in which the body (badan) rather than the breasts of 'Umar's slave women "knock together". This may be a later attempt to sanitize the report. 


\begin{tabular}{llc}
\hline \multicolumn{1}{c}{ Isnād } & Reports & Total \\
\hline Medinan & $1,2,3,10,18$ & 5 \\
Kufan & $4,5,16$ & 3 \\
Basran & $6,11,13,17,25$ & 6 \\
Meccan & 7,8 & 2 \\
Mixed & $9,12,14,15,28$ & 5 \\
Total & & $\mathbf{2 1}$ \\
\hline
\end{tabular}

\section{Analysis of the Variants}

The 'Umar report achieved wide dissemination quickly, as the isnāds listed above suggest. A number of the variants are poorly transmitted by the standards of (later) classical hadith criticism, with noticeable gaps in their routes of transmission (i.e. they are marāsill). Nonetheless, the basic integrity of the 'Umar report has been accepted by several exacting Muslim critics, including al-Bayhaqi (d. 458/1066), Ibn H.̣azm (d. 456/1064) and, more recently, Nāșir al-Dīn al-Albānī (d. 1420/1999). The latter two, interestingly, accept the authenticity of the report while rejecting its probativeness. ${ }^{48}$ These gaps in transmission already appear in our earliest attestation of the 'Umar report, the Muwatta. That multiple recensions of the Muwatta' all convey what is more or less the same version of the report speaks strongly to its inclusion in one or more "editions" published by the work's reputed author-compiler, Mālik b. Anas. The "Umar report also appears in two early independent Kufan versions, both transmitted by students of Abū Ḥanīfa. Basran and Meccan isnāds also make an early appearance, in the late second Islamic century.

All of the reports describe an encounter between 'Umar and one or more persons and involve an element of reproach. There is one exception, the report attributed by al-Qāạī al-Nu'mān to Muḥammad al-Bāqir (d. 114/732) via his son Jáfar al-Ṣādiq, the fifth and sixth imāms of the Twelver-Shi'a and Ismāîlīs, respectively. In this account, al-Bāqir is equally protective of the distinction between free and enslaved women, employing the same insult (luka'u) to enforce it. This appears to be the earliest attribution of the report to someone other than 'Umar, though one can safely assume that al-Qāḍi al-Nu'mān drew it from an already existing Kufan Shici corpus. ${ }^{49}$ In most versions of the main narrative, however, it is 'Umar

48 On the report's authenticity, see al-Bayhaqī, al-Sunan al-kubrā, 2: 321; Ibn Ḥazm, al-Muhallā, ed. Khālid al-Rabbāt et al., 19 vols. (Cairo: Dār al-falāḥ, 1437/2016), 4: 41; al-Albānī, Irwāa al-ghalül fì takhrïj ahādīth Manār al-sabül, 9 vols. (Beirut: al-Maktab al-islāmī, 1405/1985), 6: 203-04. 
who confronts the slave woman. In some variants, he reproaches Hafșa, one of the Prophet's wives, or the people of Medina generally. The question of the slave woman's owner also gave rise to conflicting answers, which may stem from the notion found in several versions of the report that 'Umar habitually confronted slave women over their problematic dress. Some accounts purport to convey information about the same episode, however. In these cases the narrators differ as to which of 'Umar's children is the guilty party: it is either 'Abd Allāh, 'Ubayd Allāh, 'Abd al-Raḥmān, or Ḥafṣa. In the other reports, Anas b. Mālik or someone in his household, Abū Mūsā al-Ash'arī, or one of the wives of the Prophet is the culprit. This confusion over identity also pertains to the slave woman herself. In most variants, she is anonymous, in one she is identified as Āqila. The variants also diverge on the nature of the confrontation. 'Umar either struck her (in most versions) or he did not; and he either reprimanded her directly, or criticized her owner (or somebody who knew them). The slave woman's response, and the insults used against her, vary accordingly. In one instance she is slow to comply, provoking 'Umar to hit her with his switch.

While the basic structure of the narrative is common to most of the accounts, in some variants 'Umar reproaches the slave woman for covering her head, in others for wearing a robe. It is notable that it is the slave woman's dressing as a free woman that is the source of temptation. The distinction suggests that sexual desire was attached to status - as though free women are inherently desirable and slave women are not. One version can be construed as making 'Umar's sexual needs explicit (an aqa'u bihā, i.e., "Such that I wished to have sex with her"). The underlying proprietary ethic is clear: 'Umar upholds the distinction between free and enslaved women, implying that the latter are subject to different modesty norms because of their status as property. This status should be clearly visible, and any attempts to subvert it should be treated with hostility.

It is only in isnād-less, later versions of the report that one finds colorful insults, including (in chronological order of their appearance) luka'u, lukā and difär (versions 22, 27 and 29, respectively). These insults tend to appear in works of figh and tafsir rather than compilations of hadith, and one suspects that they represent the elaboration of a copyist rather than a transmitter. There is, of course, the possibility that I have not recorded all of the major variants, or that some of them are lost to us forever or remain in manuscript. ${ }^{50} \mathrm{We}$

hadith materials, see Kumail Rajani, "Making Sense of Ismaili Traditions: The Modes and Meanings of the Transmission of Hadìth in the Works of al-Qāḍī al-Nu'mān (d. 363/974)," unpublished D. Phil. dissertation, University of Exeter, 2019. 
are on firmer ground with speculation on the origins of the version adduced by al-Qāḍī 'Abd al-Wahhāb, certainly a later interpolation. In this version, 'Umar upbraids slave women for wearing an $i z \bar{a} r$. This narrative makes no sense at all, as this item of clothing was worn by persons of all backgrounds, whether free or enslaved. Earlier authorites, such as the Mālikī Ibn Abī Zayd, explicitly mention slaves who wear the $i z \bar{a} r .{ }^{51}$ In short, reproaching a slave woman for wearing an $i z \bar{a} r$ is meaningless.

Two transmissions of the 'Umar report foreground what is only hinted at in the other versions: the veil/distinguishing dress item is for free women alone, "So that they will not be subject to harassment." It is this statement (what classical ușülìs call mafhüm al-mukhälafa, counterimplication ${ }^{52}$ ) that proved most problematic for some later jurists, as we shall see.

\section{Veiling, Proprietary Sexual Ethics, and the Formation of Islamic Norms of Modesty}

There are (at least) two approaches to the question of the influence of Near Eastern norms on the formation of Islamic law. One view posits the crystallisation of Islamic law in the wider Near Eastern context following the conquests. ${ }^{53}$ The other approach emphasizes—often to very different effect- the ways in which Arabian custom already reflected these influences prior to the career of the Prophet. ${ }^{54}$ These views are not mutually exclusive. This article is not the place to elaborate on the ways in which Islamic law was shaped by its

mentioned by al-Suyūți in any of the published editions of the extant parts of 'Abd b. Humayd's Musnad. See al-Durr al-manthūr fì l-tafsīr bi-l-ma’thūr, 8 vols. (Beirut: Dār al-fikr, n.d.), 6: 66o.

Mālik reportedly complained to the governor of Medina that slave women wear nothing above their izārs. See Ibn Abī Zayd, Kitāb al-Jämi' fí l-sunan wa-l-ādāb wa-lmaghāzī wa-l-tārīkh, ed. Muḥammad Abū l-Ajfān and 'Uthmān Bațțīkh (Beirut and Tunis: Mu’assasat al-risāla with al-Maktaba al-'ațīqa, 1403/1983), 212.

For the translation of mafhüm al-mukhälafa as "counterimplication," see Bernard G. Weiss, The Search for God's Law: Islamic Jurisprudence in the Writings of Sayf al-Dīn al-Ämidì (Salt Lake City: University of Utah Press, 2010), 482-93. Weiss notes that counterimplication "was not so widely regarded as productive of valid law" (at 482).

E.g. Patricia Crone's Roman, Provincial and Islamic Law: The Origins of the Islamic Patronate (Cambridge: Cambridge University Press, 1987). Cf. Benjamin Jokisch, Islamic Imperial Law: Hārūn al-Rashīd's Codification Project (Berlin: De Gruyter, 2007).

54 E.g. Wael Hallaq, The Origins and Evolution of Islamic Law (New York: Cambridge University Press, 2005). 
Late Ancient Near Eastern context, or indeed to reflect more generally on the category of "influence"; others have already done this. ${ }^{55}$

It is worth pointing out, however, that there is some (admittedly fragmentary) evidence indicating that the practice of veiling was by no means novel in Arabia in the lifetime of the Prophet. The Church Father Tertullian (d. 240 $\mathrm{CE}$ ) mentions that the women of Arabia "cover not only the head, but the face also...with one eye free, to enjoy rather half the light than to prostitute the entire face. ${ }^{n 6}$ This practice-veiling the face with the exception of one eye-is endorsed in a number of early Qur'ān commentaries. ${ }^{57}$ Similarly, other witnesses to pre-Islamic Arabian norms attest to the practice of veiling. In his massive study of women in jāhilī (pre-Islamic) poetry, Aḥmad al-Ḥüfì concludes that the evidence for veiling is extensive. ${ }^{58}$ It includes the famous Tä'iyya (poem rhyming in the letter "tâ"”) of al-Shanfarā (d. c. 525 CE). ${ }^{59}$ Since Muslim authors typically attributed loose sexual norms to jāhilì pagans, there were few incentives for them to "remember" veiling. ${ }^{60}$ It is reasonable to suggest, therefore, that like other inhabitants of the Near East in Late Antiquity, pre-Islamic Arabians were familiar with veiling and at times practiced it.

The Qur'ān makes three major sartorial interventions. In Q. 7:31, "children of Adam" are encouraged to dress appropriately "at every place of prayer," a verse most commentators understood as denouncing Arab pagans, who reportedly circumambulated the Kaba in a state of ritual nudity. ${ }^{61}$ Q. $24: 31$ instructs believing women

55 On "influence" and intertextuality see, for example, Shari Lowin, The Making of a Forefather: Abraham in Islamic and Jewish Exegetical Narratives (Leiden: Brill, 2006), 19-22, $27-38$.

56 Tertullian, "On the Veiling of Virgins," in Ante-Nicene Fathers, ed. Phillip Schaff et al., 10 vols. (Grand Rapids: Christian Classics Ethereal Library, n.d.), vol. 4, 54-81 (at 78). Available at ccel.org/ccel/schaff/anfo4.html (accessed 4/7/2020). See Yedida Kalfon Stillman, Arab Dress from the Dawn of Islam to Modern Times: A Short History, ed. N. Stillman (Leiden: Brill, 2000), 9 .

57 "Some of the [interpreters] say [yudnina] means to cover their faces and heads, leaving only one eye exposed." Al-Ṭabarī, Tafsīr, 19: 181.

58 Ahmmad al-Ḥufì, al-Mar'a fì l-shi'r al-jāhilī (2nd ed., Cairo: Dār al-fikr al-'arabī, n.d.), 375-77.

59 Dossani, "Virtue and Veiling," 72-73. For the poem see The Mufaddalīyāt: An Anthology of Ancient Arabian Odes, ed. Charles James Lyall, 2 vols. (Oxford: Clarendon, 1921), 1: 194-206.

6o Pernilla Myrne notes that the use of sexually explicit language by women in works of 'Abbāsid belles-lettres was "almost exclusively attributed to pre- and early Islamic women." See Pernilla Myrne, Female Sexuality in the Early Medieval Islamic World: Gender and Sex in Arabic Literature (London: I. B. Tauris, 2020), 113 .

$61 \quad$ E.g. Muqātil b. Sulaymān, Tafsìr, 2: 32-33; al-Ṭabarī, Tafsìr, 10: 149-54. The view that Arab pagans practiced ritual nudity is shared by early Shici commentators, e.g. 'Alī b. Ibrāhīm 
...not to show their beauty, except that which is apparent thereof (illa $m \bar{a}$ zahara minha) ; let them conceal their bosom with their head-coverings (khumürihinna). Let them not show their beauty, except to their husbands, their fathers, their fathers-in-law, their children, their step-children, their brothers, their brothers' and sisters' sons, their women (nisä̈ihinna), their slave-folk (mā malakat aymānuhunna), those male attendants lacking sexual desire (ghayri ülì l-irba min al-rijäli), and children not yet alive to it...

These instructions include both theocentric and proprietary elements. Firstly, husbands and relatives unlawful to marry are excepted from the general rule of concealment, along with "their" women (i.e. fellow Muslim women) ${ }^{62}$ and others who lack sexual desire (ghayri ülı l-irba). There is a correlation between the implied absence of (illicit) temptation and the corresponding relaxation of modesty norms. The lowering of the gaze, commended in this and the previous verse, is said to be "purer" for believers, who are reminded (24:30) that "God is aware of all that they do." Elsewhere (Q. 40:19), God "knows the treacheries of stolen glances (khä'inat al-a'yun) and what hearts conceal." These references to God's scrutiny and judgment are all theocentric. On the other hand, Q. 24:31 explicitly excludes slaves (mā malakat aymānuhunna), both male and female slaves, according to the majority of early authorities. ${ }^{63}$ These elements of qurānic modesty norms are clearly "proprietary;" slaves are excepted from a series of ostensibly theocentric norms that apply to believers across the board, as though the normal calculus of sexual desire does not apply to them. Though slaves are not the addressees of this verse, their exclusion from the general rule has clear implications for modesty norms. It is in this sense that qurānic sexual ethics - particularly with respect to veiling — represents a combination of theocentric and proprietary values.

The third sartorial intervention (Q. 33:59) was understood by commentators to enforce the distinction between the modesty norms expected of free and enslaved persons. The Prophet is commanded to "Tell your wives, your daughters and believing women generally (nisä' al-mu'minin $)$ to cover themselves in

al-Qummī (d. 307/919), Tafsīr al-Qummī, ed. al-Sayyid Muhammad Bāqir al-Muwaḥhid et al., 3 vols. (Qom: Mu’assasat al-imām al-mahdī, 1435), 1: 336. For an Ibāọī view, see Hūd b. Muḥakkam, Tafsīr, 2: 14 .

62 The commentators consider non-Muslim women to be inherently untrustworthy and likely to divulge information about the appearance of female believers: e.g. al-Ṭabarī, Tafsïr, 17: 264-65.

63 E.g. Ibn Kathīr, Tafsīr al-Qur'ān al-'azìm, ed. Sāmī b. Muhammad al-Salāma, 8 vols. (Riyadh: Dār țayyiba, 1420/1999), 6: 48 (for the majority view that free women may expose their beauty to their male and female slaves). 
their robes (yudnina 'alayhinna min jaläbïbihinna); that is better, that they be known and not harassed (yu'dhayna)..." Many commentators link this verse to episodes in which free women were mistaken for slaves and were subject to harassment, ${ }^{64}$ usually during nocturnal excursions to the toilet, ${ }^{65}$ still a concern in some parts of the world today. ${ }^{66}$ Free believing women are thus instructed to "cover themselves in their robes" to distinguish themselves from slaves and to preclude unwanted attention. This interpretation-requiring free women to distinguish themselves from slaves - is widely attested, even though the verse categorically commands "believing women" to veil. Q. 33:59, according to its most widely-attested interpretation, is thus the supreme example of proprietary attitudes in Islamic modesty regulations: it enforces the free/ slave binary.

Middle Assyrian law also makes a sartorial distinction between free and enslaved women. I should note that I am wary of asserting the unqualified "influence" of Assyrian law on Islamic law, not least because there are no obvious parallels to Islamic slave concubinage in the Late Antique Middle East (and thus, insufficient evidence of continuity). ${ }^{67}$ In any case, in Middle Assyrian law:

Wives of a man...who go out into the main thoroughfare [shall not] have their heads [bare]...[they] shall be veiled...a concubine...is to be veiled...

64 E.g. Muqātil b. Sulaymān, Tafsīr, 3: 507; Yahyyā b. Sallām, Tafsìr, 1: 440-41; 'Abd al-Razzāq, Tafsìr, 3: 5, and al-Ṭabarī, Tafsìr, 19: 181-83.

65 An understanding echoed by Ibn Sa'd (d. 230/845), Kitāb al-Ṭabaqāt al-kabìr, ed. Iḥsān 'Abbās, 8 vols. (Beirut: Dār șādir, 1968), 8: 176. For an alternative account of the verse's revelation, according to which 'Umar mistakes an unveiled free woman for a walida (slave concubine), see 'Abd Allāh b. Wahb (d. 197/812), al-Jāmi': Tafsìr al-Qur'ān li-'Abd Allāh b. Wahb, ed. Miklós Murányi, 3 vols. (Beirut: Dār al-gharb al-islāmī, 2003), 1: 72.

66 According to а ввс News report on sexual harassment in India, "The unspoken rule is that men go to the toilet only at dawn, but boys sometimes break this rule, in order to harass or molest members of the opposite sex. The women tell stories of catcalling and groping - though will never admit that this has happened to them, only to others." Divya Arya, "India's long, dark and dangerous walk to the toilet" (27 June 2014): bbc.co.uk/news/ magazine-280039513 (accessed 25/6/2020).

67 On the anomalous nature of Islamicate slave-concubinage in its Late Ancient Near Eastern context, see Majied Robinson, Marriage in the Tribe of Muhammed: A Statistical Study of Early Arabic Genealogical Literature (Berlin: De Gruyter, 2020), 107, 110-11. On the relationship between Assyrian law and the Qurān, see David Powers, Muhammad is Not the Father of Any of Your Men: The Making of the Last Prophet (Philadelphia: University of Pennsylvania Press, 2011), 177 ff.; idem, "From Nuzi to Medina: Q. 4:12b, Revisited," in Structures of Power: Law and Gender Across the Ancient Near East and Beyond, ed. Ilan Peled (Chicago: The Oriental Institute of the University of Chicago, 2018), 181-210. 
slave women shall not be veiled...if a man intends to veil his concubine, he shall assemble five or six companions and he shall veil her in their presence... ${ }^{68}$

A number of early Muslim jurists reportedly supported the veiling of slave concubines (ummahāt al-awläd), or married slaves, in contradistinction to other enslaved women. But many early Muslim jurists limit the obligation (or preference) to ritual prayer. 'Ațā' b. Abī Rabāh stipulated a khimār (head covering) for slave women married to other slaves, or to free men. ${ }^{69}$ Al-Ḥasan al-Bașrī (d. 110/728) upheld the same view for married slaves and slave concubines. ${ }^{70}$ According to Sahnūn (d. 240/854) Mālikb. Anas insisted that ummahātal-awlād veil for prayer. ${ }^{71}$ Similar doctrines are found in contemporaneous Mālikī texts, including the recently edited Mukhtașar of Abū Muș ab al-Zuhrī, which singles out the umm al-walad among slave women for veiling. The author, an important transmitter of the Muwatta $a^{3}$, remarks that it is reprehensible (yukrah) for a slave concubine to "uncover her head in prayer," a view shared by other fourth/ tenth century Mālikīs. ${ }^{72}$ Aḥmad b. Hanbal (d. 241/855) reportedly preferred that slave women pray in a khimār (head covering), though prayer without it remains valid. However, once a female slave has been emancipated (even if in

68 "Middle Assyrian Laws," in Law Collections from Mesopotamia and Asia Minor, ed. Martha T. Roth (2nd edition, Atlanta: Scholars Press, 1997), 167-69.

69 'Abd al-Razzāq, Mușannaf, 3: 88, 9o. Ibn al-Mundhir, by contrast, reports that 'Ațā' merely "preferred" that ummahāt al-awlād cover their heads in prayer. See al-Ishrāf'alā madhāhib al-'ulamā', ed. Abū Aḥmad Șaghīr Aḥmad al-Anșārī, 10 vols. (Ra’s al-Khamya: Maktabat makka al-thaqāfiyya, 1426/2005), 2: 240.

'Abd al-Razzāq, Muṣannaf, 8: 33; Ibn al-Mundhir, al-Ishrāf, 2: 240; idem, al-Ijmā̄, ed. Șaghīr Aḥmad b. Muhammad Ḥanīf ('Ajmān and Ra’s al-Khayma: Maktabat al-furqān with Maktabat makka al-thaqāfiyya, 1420/1999), 50. Saḥnūn b. Saīid al-Tanūkhī, al-Mudawwana al-kubrā, 16 vols. (Riyadh: Wizārat al-shu’ūn al-islāmiyya), 1: 94-95.

Kitāb Mukhtașar Abī Mușáab, ed. Nūr al-Dīn Shūbad (Rabat: al-Rābița al-muḥammadiyya li-l-ulamā', 1439/2018), 200. Among later Mālikīs, Abū l-Qāsim 'Abd Allāh b. al-Ḥusayn al-Jalläb (d. 378/988-9) holds that it is recommended (mustahhab) for the umm al-walad and the mukätiba (a slave subject to contractual emancipation in return for financial compensation) to veil for prayer as free women do. Conversely, it is recommended for other categories of female slaves to pray bare-headed. See al-Tafrì fífiqh al-imām Mālik $b$. Anas, ed. Sayyid Kisrawī Ḥasan, 2 vols. (Beirut: Dār al-kutub al-ilmiyya, 1428/2007), 1: 9 o. Ibn Abī Zayd (d. 386/996) states that ummahāt al-awlād must veil for prayer in his Ikhtișār al-Mudawwana wa-l-Mukhtalața, ed. Ahmad b. 'Abd al-Karīm Najīb, 4 vols. (Dublin: Markaz ajībawayh, 1434/2013), 1: 142-43. Elsewhere, he does not distinguish slave concubines from other slaves, see e.g. idem, al-Nawādir wa-l-zìādāt 'alā mā fíl-Mudawwana min ghayrihā min al-ummahāt, ed. 'Abd al-Fattāḥ Muḥammad al-Ḥilw, 15 vols. (Beirut: Dār al-gharb 
mid-prayer), veiling becomes mandatory. ${ }^{73} \mathrm{Ibn}$ Abī Shayba attributes contrasting views to earlier jurists, some of whom held that a slave woman, presumably including slave concubines, ought to "pray as she appears in public (tușalli al-ama kamā takhruj)," meaning unveiled. ${ }^{74}$ Other jurists are more explicit: "a slave woman is not required to veil [in prayer] even if she bears her master a child." 75

Most proto-Sunni jurists did not distinguish between slave concubines, married slaves and others for purposes of veiling, which they held to be neither recommended (mustahhab) nor obligatory. ${ }^{76}$ This view was shared by early Twelver-Shi'a and Ismāeilīs, as well as Zaydīs. ${ }^{77}$ We do know from one early non-Muslim account that veiling was the norm in Baghdad shortly after that city's foundation. Though sensitive to the legal distinctions between slaves and free persons (both are obligated to pray), our source is silent on the question of

al-islāmī, 1999), 1: 207. Some Mālikī authors do not refer to slave women at all, e.g. al-Qāḍī 'Abd al-Wahhāb (d. 422/1035), al-Ishrāf 'alā nukat masāil al-khilāf, ed. Mashhūr b. Ḥasan Āl Salmān, 6 vols. (Riyadh and Cairo: Dār ibn al-qayyim with Dār ibn 'affān, 1429/2008), 1: 303-04.

'Abd Allāh b. Ahmmad b. Hanbal (d. 29o/903), Masā̉il al-imām Aḥmad b. Hanbal: riwāyat ibnuhu 'Abd Allāh, 3 vols. (n.p.), 1: 210-11; Abū l-Qāsim 'Umar b. al-Ḥusayn al-Khiraqī (d. 334/945), Matn al-Khiraqū, ed. Abū Ḥudhayfa Ibrāhīm b. Muḥammad (Ṭanțā: Dār al-ṣahāāba, 1413/1993), 25.

Ibn Abī Shayba, Mușannaf, 3: 114. Similar reports can be found in 'Abd al-Razzāq, Mușannaf, 3: 89. Ibid. did not require any slave woman to veil for prayer "even if she reaches a hundred years [of age] or bears her master a child," a view endorsed by Muhammad and his teacher Abū Ḥanīfa (d. 150/767). See Kitāb al-Āthār, 1: 610-13. Al-Shāficī (d. 204/820) does not mention slaves in his discussion of veiling: Kitāb al-Umm, ed. Rif'at Fawzī 'Abd al-Mutțalib, 11 vols. (Cairo: Dār al-wafā̄, 1422/2001), 2: 199. His student, Ismāīl b. Yahyāa al-Muzanī (d. 264/878-8), does refer to slaves, however. See Mukhtașar al-Muzani fi furū al-shāficìya, ed. Muhammad 'Abd al-Qādir Shāhīn (Beirut: Dār al-kutub al-ilmiyya, 1419/1998), 27. The view that no slave woman of any kind is required to veil is also found in Abū l-Abbās al-Ṭabarī, (d. 335/946-7), al-Talkhīṣ, ed. 'Ādil Aḥmad 'Abd al-Mawjūd and 'Alī Muhammad Mu'awwaḍ (Maktabat Nizār Mușțafā al-Bāz, n.d.), 164. Ibn al-Mundhir attributes the nonrequirement view to a range of early figures, noting that there is no distinction between different kinds of female slaves in this regard: al-Ishräf, 2: 239-40. See also idem, al-Iqnāa, ed. 'Abd Allāh al-Jibrīn, 2 vols. (Riyadh: Maktabat al-rushd, 1414), 1: 144. See e.g. Ibn Bābawayh (d. 38o/991), Man lā yahḍuruhu al-faqīh, ed. 'Alī Akbar al-Ghaffārī, 4 vols. (Qumm: Mu’assasat al-nashr al-islāmī, 1429), 1: 373 (where only the slave woman who has paid all the installments required for her emancipation is required to veil). Shaykh Mufìd (d. 413/1022) makes no distinction between different categories of enslaved women: al-Muqni'a (Qumm: Dār al-hudā, 1431), 151. Shaykh al-Ṭāíifa al-Ṭūsī (d. 46o/1067) reinterprets reports permitting women to pray bare-headed by arguing that these reports 
whether slaves veiled or not. ${ }^{78}$ There is, moreover, no suggestion in the sources of any equivalent to the Assyrian legal procedure for veiling slave concubines.

There is a difference between holding an act to be non-obligatory-as most early jurists did for the veiling of female slaves - and prohibiting it. The distance between the two positions, one might say, is the length of 'Umar's switch. Since this distinction seems to be lost already in most of our earliest sources, reviewed above, I shall explore the possible rationale for 'Umar's reported actions by drawing on recent scholarship.

Eli Alshech has argued that the assertion that the purpose of veiling (and related practices) was to minimize sexual temptation is not persuasive. ${ }^{79}$ Sexual temptation was part of the impetus, but it is not the whole story. No less important was the need, inter alia, "to create a private sphere." 80 The first of three examples adduced by Alshech to emphasize this point is the veiling of slaves: "...if preventing lust and sexual desire were their only concern, why did many scholars differentiate between the dress code of female slaves and that of free women?"81 Alshech observes that the equation of modesty laws with sexual morality began to receive greater emphasis in the "late classical period" (i.e. the fourth-eighth/tenth-fourteenth centuries). ${ }^{82}$ Similarly, Youshaa Patel calls attention to the multiple purposes of veiling norms in the formative period. He emphasizes their "function of materializing hierarchical social distinctions between women." ${ }^{83}$ Patel remarks that the "Umar report demonstrates how "clearly the aim of maintaining visible class distinctions between slavegirls and freewomen [sic] in public life trumps the aim of controlling male excess sexual desire." 84 Both Alshech and Patel emphasize status

concern slave women and young girls. See Shaykh al-Ṭāifa al-Ṭūsī, al-Istibṣār fi māa ukhtulifa min al-akhbār (Beirut: Mu’assasat al-a'amī, 1426/2005), 221; see idem, Tahdhīb al-ậkām fì sharh al-Muqni'a, ed. 'Alī Akbar al-Ghaffārī, 10 vols. (Tehran: Dār al-kitāb al-islāmiyya, 1384), 2: 232-33. For the Ismāīilīs, see al-Qāḍī al-Nưmān, Da'āim, 1: 187. For the Zaydī view, see al-Tāj al-muhadhdhab li-ậkām al-madhhab: sharh matn al-Azhār fì figh al-äimma al-aṭhār, 4 vols. (Sanaa: Dār al-ḥikma al-yamāniyya, 1414/1993), 1: 100. Wan Lei, "The First Chinese Travel Record on the Arab World: Commercial and Diplomatic Communications during the Islamic Golden Age," Qiraat, 1: 7 (1438/2016-17), 1-52, at 17. Eli Alshech, "Out of Sight and Therefore Out of Mind: Early Sunnī Islamic Modesty Regulations and the Creation of Spheres of Privacy," Journal of Near Eastern Studies, 46: 4 (2007), 267-9o, at 270-71. Ibid., 272. See also idem, "'Do Not Enter Houses Other than Your Own': The Evolution of the Notion of a Private Domestic Sphere in Early Islamic Sunnī Thought," Islamic Law and Society, 11: 3 (2004), 291-332.

81 Alshech, "Out of Sight," 271.

82 Ibid., 275. For the term "late classical," see ibid., 269.

83 Youshaa Patel, "Muslim Distinction," 318.

84 Ibid. 
considerations over other factors. That status trumped sexual temptation in the minds of early jurists is clear evidence of the continued importance of the proprietary ethic. In a purely theocentric system, there would be no room for the distinction between free and enslaved women. By contrast, Ze'ev Maghen has characterized the Islamic approach to the control of sexuality as belonging to the "building strong walls" approach. The "building strong walls" approach, in contrast to the "building strong men" approach, implies a less than sanguine view of human nature. ${ }^{85}$ The "Umar report thus embodies what Maghen would recognize as an exception to the general rule. It does not fit clearly into either conceptual scheme.

There is much evidence to suggest that no later the third Islamic century, the fear of fitna had begun to challenge the view that veiling maintained social hierarchies. The increased fear of fitna anticipates changes that, according to Alshech, took place in the late classical period (the fourth-eighth/tenth-fourteenth centuries). Asked if it is reprehensible (tukrah) for slave women to veil in public, Ahmad b. Hanbal replied that a beautiful slave woman should in fact do so (idha kānat jamila tantaqib). ${ }^{86}$ The main consideration here is the potential for temptation. Similarly, Mālik b. Anas is reported to have harangued the governor of Medina to prevent slave women from going about topless, albeit without success. ${ }^{87}$ 'Abd al-Malik b. Habīb (d. 238/852) himself clearly experienced temptation in Medina, but nonetheless maintained the free/slave distinction. ${ }^{88}$ By the end of the late classical period, the moralistic dimensions of veiling became more pronounced, as in the Madkhal of Ibn al-Hạajj (d. 737/1336). ${ }^{89}$

85 Ze'ev Maghen, "See No Evil: Morality and Methodology in Ibn al-Qațțān al-Fāsìs Ahkām al-Nazar bi-Hāssat al-Bașar," Islamic Law and Society, 14: 3 (2007), 342-90, at 344-45. The full title is Ihkām al-nazar fì ahkām al-nazar bi-ḥāssat al-baṣar, ed. Idrīs al-Ṣamadī (Damascus: Dār al-qalam, 1433/2012), 50-51.

86 Al-Kawsaj (d. 251/865), Masāill al-imām Ahmad b. Hanbal wa Ișhāa b. Rāhawayh, 10 vols. (Medina: al-Jāmi'a al-islāmiyya, 1425/2004), 9: 4706; Abū Bakr al-Khallāl (d. 311/923), A ḥkām al-nisā', ed. 'Umar 'Abd al-Mun'im Salīm (Beirut: Mu’assasat al-rayyān, 1423/2002), 6o-61.

87 Ibn Abī Zayd, Kitāb al-Jāmi', 212. He notes that Mālik recommended beating slave women who failed to cover their breasts.

88 Ibn Habīb writes, "I did not see a slave woman in Medina-even if she was beautiful $\left(r \bar{a} i^{\prime} a\right)$ - with a covered head... Slave women [should] uncover their heads so as to be distinguishable from free women," Ibn Ḥabīb, Kitāb adab al-nisā’, 229. Ibn Ḥabīb held that the ruling for slave concubines (sarārī) is the same as for other slave women (ibid.).

89 Ibn al-Ḥājj, al-Madkhal, 4 vols. (Cairo: Maktabat dār al-turāth, n.d.) 1: 241-45. See Huda Lutfi, "Manners and Customs of Fourteenth-Century Cairene Women: Female Anarchy versus Male Shar i Order in Muslim Prescriptive Treatises," in Women in Middle Eastern History: Shifting Boundaries in Sex and Gender, ed. Nikki R. Keddie and Beth Baron (New Haven: Yale University Press, 1991), 99-121. 
According to Alshech, the jurists' equation of veiling with minimizing sexual temptation increases from the late classical period onwards (fourth-eighth/ tenth-fourteenth centuries); the (theocentric) notion of curtailing fitna as the ratio legis of modesty norms becomes more prevalent. Postclassical jurists, and the moderns who follow their example-like al-Kawthari- - usually insist that free women conceal their faces, an opinion much less common in the formative period. The view that face-veiling is obligatory becomes the standard opinion in authoritative late works of the four Sunni legal schools. Only with the Hanbalīs does obligation represent continued fidelity to madhhab doctrine. The obligation is attested in the "canonical" works of the four Sunni schools authored immediately before the modern period. ${ }^{90}$ The non-veiling of slaves, on the other hand, remains the standard position in the four Sunni legal schools. This distinction suggests an increasing divergence between the norms prescribed for free and enslaved women in the postclassical period, ${ }^{91}$ a discussion that evidently continued into the early fourteenth/twentieth centuries. As the modesty zone of free women expanded to encompass the face and hands - owing no doubt to the "corruption of the present age —" the modesty zone remained as it was for enslaved women. In other words, according to the majority of Sunni jurists, the tensions between the theocentric and proprietary ethics remained in place. As the argument for concealing the bodies of free women became increasingly popular, there does not seem to have been a corresponding doctrinal shift in the case of slaves. The non-veiling of slave women was, however, challenged.

No later than the fifth/eleventh century, a minority of Muslim jurists began to insist that the same veiling norms apply to free and enslaved women, a position that represents the triumph of theocentrism. This seems to be a rare opinion, of which I have been able to locate only a handful of examples. Tentatively, therefore, I suggest that this insistence is found most commonly among jurists of a textualist bent, including Ibn Ḥazm, Ibn al-Qațțān (d. 628/1231) and Abū Ḥayyān al-Gharnāțī (d. 745/1344). Among other textualists, Ibn Taymiyya (d.

90 On face veiling, see Ibn 'Ābidīn, Radd al-muhtār $r$, 406 (reiterating the view of al-Hașkafi, d. 1088/1677); Ibrāhīm al-Bayjūrī (d. 1276/186o), Hāāshiyat al-Bayjūrī, ed. Muhammad 'Abd al-Salām Shāhīn, 2 vols. (Beirut: Dār al-kutub al-ilmiyya, 1420/1999), 1: 337 (reiterating the view of Abū Shujā', d. 590/1194); Manșūr al-Buhūtī (1051/1641), Kashshāf al-qinā' 'an matn al-Iqnā'c 6 vols. (Beirut: 'Ālam al-kutub, 1403/1983), 1: 266, and Shams al-Dīn al-Dusūqī (d. 1230/1815), Hiāshiyat al-Dusūqī 'alā l-Sharh al-kabìr, 4 vols. (Cairo: 'Īsā al-Bābī al-Ḥalabī, n.d.), 1: 214. See also Stowasser, Women in the Qur'an, Traditions, and Interpretation, 93-94. Ibn 'Ābidīn, Radd al-muhtārr, 1: 405; al-Bayjūrī, Hāāshiya, 1: 271; al-Buhūtī, Kashshāf al-qinā', 1: 266, and al-Dusūqī, Hêashiya, 1: 213. 
728/1328) and his disciple Ibn al-Qayyim (d. 751/1350) are more restrained, stipulating veiling for slaves only in cases of fitna. ${ }^{92}$ Among jurists of the postclassical period, al-Shawkānì (d. 1250/1834) summarizes the arguments of both sides of the debate without clearly committing himself either way, attributing the pro-veiling view exclusively to the Zāhirīs. ${ }^{93}$

Among the jurists who explicitly express their support for the veiling of slaves, Ibn al-Qațtān limits himself to a passing remark that the command in Q. 24:31 that women "not reveal their beauty, except what is apparent thereof" applies to slave women no less than to free ones. ${ }^{94}$ Similarly, Abū Hayyān observes that the instruction that "believing women" should cover themselves with their robes (Q. 33:59) is directed at both groups equally; if anything "the fitna of slave women is greater owing to their going about freely (tașarrufihinna), in contradistinction to free women; excepting [slave women] from [the category of] "women" generally requires clear proof (dalïl wädih)." ${ }^{95}$ The explicit emphasis on fitna here bears out the point made by Alshech. The same concern is reiterated by Ibn Hazm, who is by far the most strident (and eloquent) critic of the teachings of the madhhab-jurists on the question. In an extended discussion of their arguments, he skewers his opponents for their inconsistencies, lack of rigor and gross disregard for the wellbeing of enslaved

Ibn Taymiyya generally upholds the distinction between free and enslaved women, but in one place deploys the fasād al-zamān argument to the effect that slave women must occasionally veil (as in the view attributed to Ahmad b. Hanbal): "If men were to let [their] beautiful Turkish slave women walk about in [such] places and times [as these], as they used to [walk about in the time of the Companions], this would give rise to great corruption." See Ibn Taymiyya, Majmū $\bar{u}^{`}$ al-fatāwā, ed. Muhammad b. 'Abd al-Raḥmān b. Qāsim, 35 vols. (Medina: Majma' al-Malik Fahad, 1995/1416), 15: 418. For the opposing view, see ibid., 15: 327 (reiterating the standard opinion of the Hanbalīs); idem, al-Fatāwa al-kubrā, 6 vols. (Beirut: Dār al-kutub al-ilmiyya, 1408/1987), 5: 325 (reporting that the area from a slave woman's navel to her knee is 'awra, and critiquing the view of some Hanbālīs that a slave woman's 'awra is limited to her pudendum and anus); idem, al-Mustadrak 'alā Majmū' al-fatāwāa, ed. Muḥammad b. 'Abd al-Raḥmān b. Qāsim, 5 vols. (n.p., 1418), 3: 66; also idem, Sharh al-'Umda, ed. Muḥammad Ajmal al-Ișlāḥī et al., 5 vols. (Mecca: Dār ālam al-fawāìd, 1436), 2: 270-78 (a long discussion in which Ibn Taymiyya upholds the distinction between free women and slaves). Cf. Ibn al-Qayyim, I'läm al-muwaqqi'ìn 'an rabb al-ālamin, ed. Mashhūr b. Ḥasan Āl Salmān, 7 vols. (Dammam: Dār Ibn al-Jawzī, 1423), 3: 284-85 (where he distinguishes between 'awra in prayer and 'awra generally, and between slaves generally and slave concubines; the latter are customarily veiled). Al-Shawkānī, Nayl al-awtāar, ed. 'Iṣām al-Dīn al-Ṣabābatī, 8 vols. (Cairo: Dār al-ḥadīth, 1413/1993), 2: 79-8o.

94 Ibn al-Qațāan, Iṇkām al-nazar, 170.

95 Abū Ḥayyān al-Gharnāṭ̂i, al-Baḥr al-muhüt fì l-tafsìr, ed. 'Ādil Aḥmad 'Abd al-Mawjūd and 'Alī Muḥammad Mu'awwaḍ, 8 vols. (Beirut: Dār al-fikr, 1420), 7: 240. 
Muslim women. ${ }^{96}$ It is a searing, searching critique, teeming with righteous indignation, and it represents the exact opposite of the view Alshech attributes to early classical scholars. On the proper interpretation of Q. 24:31 (typically understood, as noted, as meaning that free women must distinguish themselves from slaves), Ibn Ḥazm exclaims:

We declare ourselves innocent before God of this pernicious interpretation (tafsir fäsid), which is either the error of a learned one-combining virtue and obliviousness (fädil ghäfil) — or the fabrication of a dissolute liar. [This is] because [the non-veiling of slaves] suggests that God the most high unleashed the depraved (fussāq) against Muslim slave women, a terrible calamity! No two Muslims disagree that illicit sex is prohibited with both free women and slave women, or that the punishment for such relations is the same, whether committed with one or the other...for this and other reasons it is evident that no opinion of anyone after the Prophet - may God have mercy on him and grant him peace—can be accepted unless it is supported by a chain of narrators [directly] to the Prophet. ${ }^{97}$

Ibn Hazm gives short shrift to the 'Umar report. Because it is not a Prophetic hadith, it is not probative, particularly given the alleged disagreement of early Muslims on the question. ${ }^{98} \mathrm{He}$ is more of a scripturalist than the proto-Sunnis, who granted non-scriptural sources a much more considerable place than Ibn Hazm did in their jurisprudence. ${ }^{99}$ Ibn Hazm's methods and conclusions are echoed by al-Albānī, who refers to numerous sources and presents what is, to the best of my knowledge, the most sophisticated argument that free and enslaved Muslim women are subject to the same modesty norms. ${ }^{100}$ To come full circle, and to return to the point on which I began this article, al-Albānī refutes the claim of an anonymous contemporary that the hijāb is now obsolete on the grounds that veiling is premised (as in interpretations of Q. 33:59)

96 Ibn Hazm, al-Muhallā, 4: 38-48 (note his critique of the claim that women's faces are 'awra, at $37-38)$.

$97 \quad$ Ibid., $38-39$.

98 Ibid, 41.

99 See Scott Lucas, "Where are the Legal Hadìth? A Study of the Mușannaf of Ibn Abī Shayba," Islamic Law and Society, 15: 3 (2008), 283-314.

100 Al-Albānī, Irwāà al-ghalīl, 6: 203-04 (on the isnāds of the 'Umar report). See also idem, Jilbāb al-mar'a al-muslima fì l-Kitāb wa-l-sunna (Cairo: Dār al-salām, 1423/2002), 90-103 (citing a range of jurists, including Ibn Ḥazm and al-Jașșās). In ibid., 104, al-Albānī argues (like Ibn Hazm) that concealing the face is not obligatory, an issue to which he devoted a separate treatise, al-Radd al-mufhim (Amman: al-Maktaba al-islāmiyya, 1421). 
on a free/slave binary that no longer exists. ${ }^{101}$ There is no evidence to suggest that al-Albānī was aware of the writings of Nazīra Zayn al-Dīn, but it is unlikely that he would have been impressed by them. ${ }^{102}$ At least among the abovementioned textualist jurists, one finds that the tension between proprietary and theocentric ethics is fully resolved, unambiguously, in favor of the latter.

\section{Conclusion}

The unveiling of slaves is grounded in the proprietary conception of sexual ethics. If juristic opinion had been guided entirely by theocentric normsthe fear of fitna - the distinction between slaves and free women would not have arisen. The increased importance of theocentric norms from the early to late classical periods suggests that less "permissive" attitudes towards sexual morality became the norm once the schools had more or less monopolized the production of Islamic law. Archaic figh data also points to the decreasing permissiveness noted by Alshech. ${ }^{103}$ Though some jurists who dissented from the teachings of the legal schools extended the obligation of veiling to slaves, on theocentric grounds, this was a minority opinion that had only minimal influence on the school jurists. There are good reasons for this lack of influence, not least the presence of the free/slave binary in the Qurann, according to which slaves are exempted from the general rule (Q. 24:31) that women "conceal their beauty, except that which is apparent thereof." Azam's characterization of the tensions in Islamic sexual ethics is thus very appropriate.

101 Al-Albānī, Jilbāb al-mar'a al-muslima, 93. I have not been able to identify the author of al-Qur'än wa-l-mar'a, whose author claims that "the command [to veil] was addressed to a particular temporal necessity (d̦arūra zamaniyya khāsșa)." Khaled Abou El Fadl adopts the same view, writing that: “...these verses seem to address a very specific, and even peculiar, historical social dynamic. The interaction between the text and the text's social context is not easily transferable or projectable to other contexts." See Khaled Abou El Fadl, Speaking in God's Name: Islamic Law, Authority and Women (Oxford: Oneworld, 2013 e-book edition), 482. In ibid., 483-84 Abou El Fadl refers to the 'Umar report and makes other points about the free/slave binary, none of which is original.

Al-Albānīs father and other pious Albanians fled the rule of Zog I (r. 1347-58/1928-39), a secularist despot under whose rule unveiling was officially encouraged (or enforced, according to some accounts). See Nathalie Clayer, "Behind the veil: the reform of Islam in interwar Albania or the search for a "modern" and "European" Islam," in Anti-Veiling Campaigns in the Muslim World: Gender, Modernism and the Politics of Dress, ed. Stephanie Cronin (London: Routledge, 2014), 231-51.

103 E.g. early views permitting the use of slaves for "sexual hospitality," an opinion that would be unthinkable to later Sunnis. See, for example, Ibn al-Mundhir, al-Awsaț min al-sunan 
Slaves are subject to the same moral imperatives as other human beings, with some exceptions (e.g. Q. 4:25); but they are also property, subject to most of the same transactional rules as other items of property. This ambivalence in the legal status of slaves is highlighted by Jalāl al-Dīn al-Mahallī (d. 864/1459), who observes in the case of blood-money that

...there is indecision [as to] whether he [viz. the slave] is [analogous] to a free human-from the perspective that he is a human-or an animal-from the perspective that he is property. He resembles property more than he resembles a free human, through the proof that he is sold, can be inherited, or declared an endowment...[sic $]^{104}$

Al-Mahallî's opinion should not be taken at face value. As Behnam Sadeghi reminds us, the "legal reasons" a jurist assigns to particular rulings are fluid. ${ }^{105}$ Al-Mahallī defends the Shāfi'i view against the Ḥanafiss, who held that the blood-money due for slaves is slightly less than the amount for free persons of equivalent status (e.g. religion). The Shāfi'i doctrine is that the blood-money due for a slave is his or her sale price, however high this may be (though many set a maximum amount). In advocating the Shāfici view, al-Mahallī analogizes slaves to property rather than to human beings. ${ }^{106}$

Notwithstanding these qualifications, the free/slave distinction remains meaningful. Jurists interested in expounding the wisdoms of the law similarly appealed to the status of slaves as property to explain their diminished modesty zone. Al-Qaffāl al-Kabīr (d. 365/976), commenting on the difference, writes that a slave woman is merely "one type of property (sil'a min al-sil'); those who purchase her must turn her around [to view her from all angles]."107 The same understanding is found in adab (belles-lettres) texts. In his (in)famous Epistle

wa-l-ijmā' wa-l-ikhtilāf, ed. Muḥammad 'Abd al-Salām (al-Fayyūm: Dār al-falāḥ, 20o9), 8: 402. Some prominent Twelver-Shi'a permit a slave owner to loan his slave women to others for sex. See al-Kulaynī (d. 329/941), al-Käfì (Beirut: Manshūrāt al-fajr, 1328/2007), 5: 282-84; al-Ṭūsī, al-Istibṣār, 537-38. jurisprudence pamphlet, trans. Musa Furber (Kuala Lumpur: Islamosaic, 2014), 57. For a comparable discussion, see Sohaira Z. M. Siddiqui, Law and Politics under the Abbasids: An Intellectual Portrait of al-Juwayni (Cambridge: Cambridge University Press, 2019), 210. Sadeghi, The Logic of Law Making, 147-48.

106 See e.g. al-Sarakhsī, al-Mabsūt, 27: 28-29.

107 Abū Bakr Muḥammad al-Shāshī, Maḥāsin al-sharīa fí furū' al-shāficìyya, ed. Muḥammad 'Alī Samak (Beirut: Dār al-kutub al-ilmiyya, 1428/2007), 89. On the Maḥāsin, see Ahmed El Shamsy, "The Wisdom of God's Law: Two Theories," in Islamic Law in Theory: Studies on Jurisprudence in Honor of Bernard Weiss, ed. A. Kevin Reinhart and Robert Gleave (Leiden: 
on Singing Girls, al-Jāhiz (d. 255/868) saucily remarks that female slaves "are a variety of merchandise.... and both vendor and purchaser need to examine the piece of goods carefully, and subject it to a close scrutiny [sic]." 108 Prurience aside, it is clear that slaves were subject to different standards of morality than free persons, and that these reduced expectations are based on the view that they are ultimately less than fully human. In Islamic law, the non-veiling of slaves is therefore a function of proprietary ethics: slaves are literally property and, as such, are subject to different rules than free persons.

The view that veiling is rooted in modesty norms that distinguish free women from slaves has serious moral implications that it would be remiss to leave unaddressed in this article. In her critical historiography of Islamic legal studies, Ayesha Chaudhry rightly emphasizes the need for scholarship to be morally responsible. ${ }^{109}$ Academic research never takes place in a vacuum, and however much the scholar cultivates an attitude of disinterestedness, she or he can never entirely escape the political implications of their work. In his article on Orientalism and waqf (endowment) law in French Algeria and British India, David Powers has demonstrated that even otherwise sound academic research can have deleterious social consequences. ${ }^{110}$ Research can be instrumentalized for nefarious ends. ${ }^{111}$

Reformists in the early twentieth century CE, such as Nazīra Zayn al-Dīn, held that the hijäb is a hidebound and archaic institution. She and many of her contemporaries linked veiling to material and intellectual progress. "Those un-covered nations (al-umam al-säfira)," she writes, "are the ones whose research has uncovered the secrets of nature and have subjugated the elements to their

Brill, 2014), 19-38, at 24-26. See also al-Shawkānī, Fath al-qadìr, 6 vols. (Damascus and Beirut: Dār Ibn Kathīr with Dār al-kalim al-țayyib, 1414), 3: 561.

108 Al-Jāhiz, The Epistle on Singing-Girls of Jāhiz, ed. and trans. A. F. L. Beeston (Warminster: Aris and Phillips, 1980), 24. The treatise includes an extended argument against the modesty norms advocated by proto-Sunnis, including face-veiling and the commitment to sexual segregation (16-20). In certain respects, al-Jāhiz anticipates the views of twentieth century reformists. On the characterization of the Epistle, see Ignacio Sánchez, "Reading Adab as Fiqh: al-Ğāhiziz's Singing-Girls and the Limits of Legal Reasoning (Qiyās)," Bulletin d'Études Orientales, 60: 1 (2012), 203-21.

109 Ayesha Chaudhry, "Islamic Legal Studies: A Critical Historiography," in The Oxford Handbook of Islamic Law, ed. Anver M. Emon and Rumee Ahmed (Oxford: Oxford University Press, 2018), 5-43, at 14-15.

110 David S. Powers, "Orientalism, Colonialism, and Legal History: The Attack on Muslim Family Endowments in Algeria and India," Comparative Studies in Society and History, 31: 3 (1989), 535-71, at 545-53. 
will... As for veiled nations (al-umam al-mutahajjiba)... They only sing of glories past." 112 But the hijāb — or any sartorial or social practice-is amenable to multiple interpretations, as evidenced by a large body of scholarship on the varied significations of veiling in Muslim contexts. It is a point that bears repeating. ${ }^{113}$ In her Veil, Rafia Zakaria has discussed no fewer than five major resonances of the practice, ranging from "submission" and "purity" to "feminism," "rebellion" and "subversion."114 In A Quiet Revolution, Leila Ahmed writes about her realization that the hijāb can serve as a symbol of feminist empowerment, as on American college campuses. ${ }^{115}$ Just as Muslim jurists have attributed diverse rationales to discrete points of legal doctrine, ${ }^{116}$ Muslim women can and do exercise their agency in attributing diverse rationales to the hijāb.

Whatever the religious "authenticity" or contemporary resonances of Muslim veiling practices, the significance of veiling to Muslims has a history - subject to the constraints of the sources - that can be traced. I have sought to trace the earlier chapters of that history, without depriving modern Muslims of their agency to assign radically different meanings to the veil. That veiling symbolised the distinction between free and enslaved women, as exemplified by the 'Umar report, and that later jurists generally upheld or even accentuated the distinction, are conclusions that may lead in any number of directions. It is clear, however, that whichever direction believers choose to pursue, they must take responsibility for their interpretive choices. ${ }^{117}$

(Oxford: Oxford University Press, 2013), 17-20; Aysha A. Hidayatullah, Feminist Edges of the Qur'an (Oxford: Oxford University Press, 2014), ix-x, 192-93.

112 Zayn al-Dīn, "al-Sufür wa-l-hijāb," 131.

113 See, for example, Azza Karam, "Veiling, Unveiling, and the Meanings of "the Veil": Challenging Static Symbolism," Thamyris, 3: 2 (1996), 219-36; Fadwa El Guindi, Veil: Modesty, Privacy and Resistance (Oxford: Berg, 1999), and Emma Tarlo, Visibly Muslim: Bodies of Faith (Oxford: Berg, 2010).

114 Rafia Zakaria, Veil (New York: Bloomsbury, 2017). See also Sahar Amer, What is Veiling? (Edinburgh: Edinburgh University Press, 2014).

115 Leila Ahmed, A Quiet Revolution: The Veil's Resurgence, from the Middle East to America (New Haven: Yale University Press, 2011), 207-11. Ahmed's dislike for veiling is a function of her antipathy for "Islamism" (3-5); for her identity issues, see idem, A Border Passage: from Cairo to America: A Woman's Journey (London: Penguin, 200o), 148-50. See also Fatima Mernissi, Dreams of Trespass: Tales of a Harem Girlhood (Cambridge: Perseus, 1994).

116 Sadeghi calls the rationales jurists assign to rulings "legal reasons," and emphasizes that they are after-the-fact justifications only loosely connected to the doctrines they are supposed to support: The Logic of Law Making, 147-48.

117 Kecia Ali, Sexual Ethics and Islam: Feminist Reflections on Qur'an, Hadith, and Jurisprudence (Oxford: Oneworld, 2016), 198-99. 


\section{Acknowledgements}

I thank the following (in alphabetical order) for their comments on the initial draft of this essay: Robert Gleave, Peter Gray, Yossef Rapoport, Aaron Rock-Singer, Tariq al-Timimi and Saadia Yacoob. I thank Maroussia Bednarkiewicz for designing the isnād diagram. I also wish to thank David Powers and the two anonymous reviewers for their critical and constructive comments. Any remaining faults are my own. This article is dedicated to Robert Gleave. 


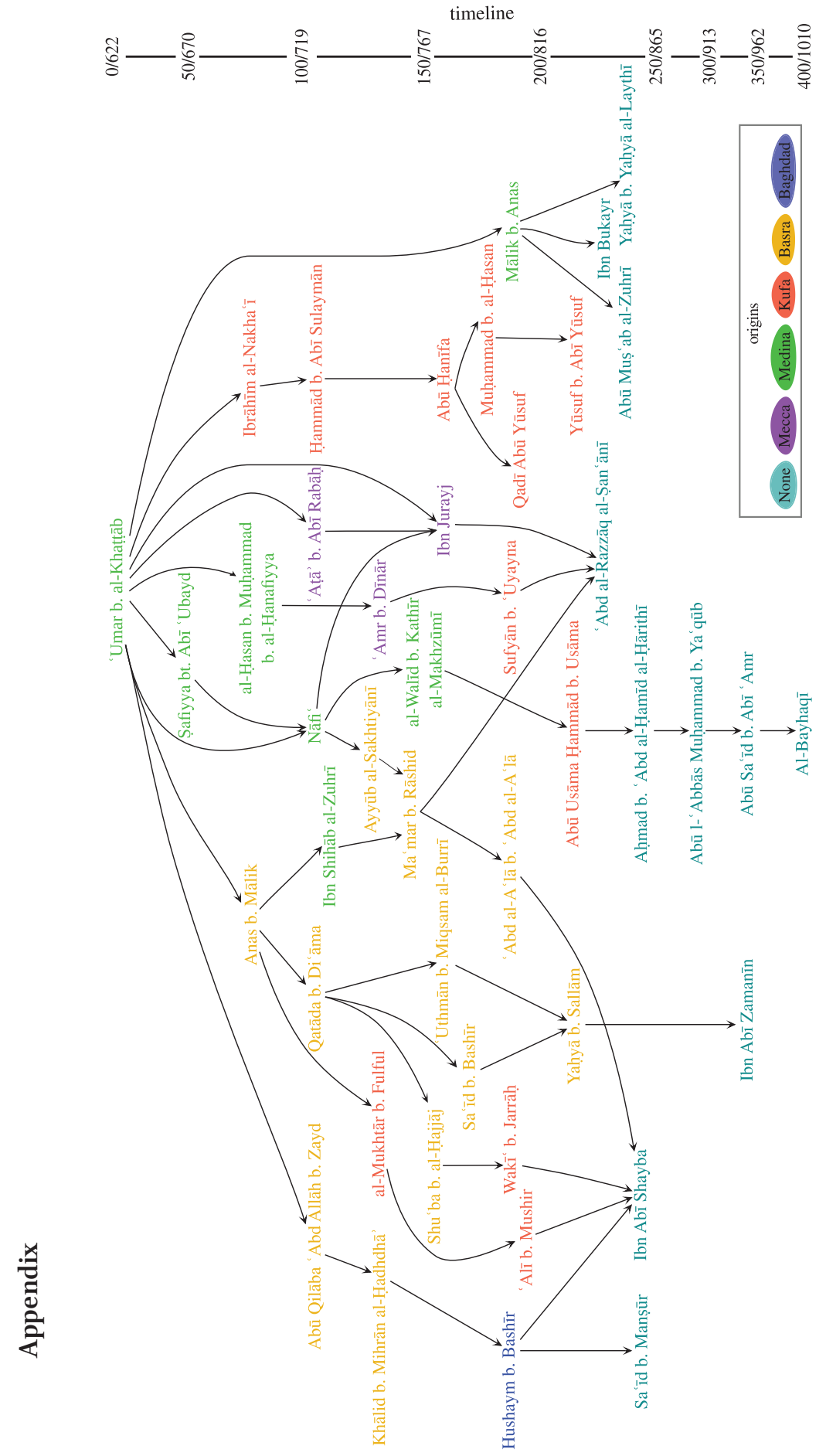

